\title{
Populismos y procesos identificatorios: un contrapunto entre dos figuras mediadoras del Peronismo en Argentina y el Gaitanismo en Colombia ${ }^{1}$
}

\section{Populisms and identification processes: a counterpoint between two mediating figures of Peronism in Argentina and Gaitanism in Colombia}

\author{
Ana Lucía Magrini \\ Consejo de Investigaciones Científicas y Técnicas (CONICET) - Centro de Historia \\ Intelectual de la Universidad Nacional de Quilmes (UNQ) Quilmes, Argentina. \\ analucia.magrini@gmail.com | https://orcid.org/0000-0002-4233-0855
}

Recibido: 04 de abril de 2020. Aprobado: 18 de Junio de 2020

DOI: $10.25100 /$ hye.v16i55.10774

Artículo de investigación

¿Cómo citar este artículo? / How to quote this article?

Magrini, Ana Lucia. "Populismos y procesos identificatorios: un contrapunto entre dos figuras mediadoras del Peronismo en Argentina y el Gaitanismo en Colombia". Historia y Espacio, vol. 16 n $^{\circ} 55$ (2020):1-27. Doi.org/10.25100/hye.v16i55.10774.

\footnotetext{
${ }^{1}$ Este artículo se enmarca en el Proyecto de Investigación Científica y Tecnológica (PICT 2017-3955), titulado "Populismos, identidades políticas y violencia(s) en Argentina y Colombia"; pesquisa financiada por el Fondo para la Investigación Científica y Tecnológica (FONCyT) de la Agencia Nacional de Promoción Científica y Tecnológica, en la que me desempeño como Investigadora Responsable. Agradezco a Mercedes Barros y a Cristian Acosta Olaya por sus observaciones y comentarios realizados a una versión preliminar de este trabajo, presentado en el Workshop sobre populismos e identidades políticas realizado en la ciudad de Córdoba, los días 9 y 10 de octubre del 2019.
} 


\title{
Resumen
}

En este artículo se propone deconstruir algunas ideas, muchas veces presupuestas, en los estudios sobre populismo, según las cuales: (1) estudiar a los líderes es sinónimo de estudiar a los movimientos; (2) que sólo es pertinente comparar casos homólogos; (3) que los populismos se caracterizan por una comunicación directa en la que participan necesariamente tres actores: el líder, el pueblo y sus enemigos; (4) y que los populismos tienden a homogeneizar las identidades políticas. A contramano de estas premisas se abordan aquí dos experiencias populistas disímiles, el primer peronismo en Argentina y el gaitanismo en Colombia, entendiendo a los populismos como discursos caracterizados por construir identificaciones políticas contingentes y constitutivamente heterogéneas. Para ello se analizan procesos de identificación de dos figuras mediadoras y especialmente controversiales durante el proceso de emergencia del peronismo y del gaitanismo: Cipriano Reyes y J. A. Osorio Lizarazo, respectivamente.

Palabras clave: Peronismo, Gaitanismo, Populismo, Identificaciones Políticas.

\begin{abstract}
This article proposes to deconstruct some ideas (often presupposed) in populism studies, according to which: (1) studying leaders is synonymous with studying movements; (2) that it is only pertinent to compare homologous cases; (3) that populisms are characterized by direct communication which necessarily involves three participants, the leader, the people and their enemies; (4) and that populisms tend to homogenize political identities. Contrary to these premises this article intends to examine two dissimilar populist experiences, the first Peronism in Argentina and Gaitanism in Colombia, understanding populisms as discourses characterized by constructing contingent and constitutively heterogeneous political identifications. For this purpose, identification processes of two mediating and especially controversial figures during the process of emergence of Peronism and Gaitanism are analyzed: Cipriano Reyes and J. A. Osorio Lizarazo, respectively.
\end{abstract}

Keywords: Peronism, Gaitanism, Populisms, Political Identifications. 


\section{Introducción: populismos en clave identitaria, heterogénea y comparada}

Los estudios sobre populismos latinoamericanos parecen caer con insistencia en algunos presupuestos no del todo explícitos, como la idea que sostiene que estudiar a los líderes (sus trayectorias, sus acciones y sus intenciones) es sinónimo de analizar los movimientos, que sólo es posible (o pertinente) comparar casos homólogos, que los populismos se caracterizan por una comunicación directa (sin mediaciones) en la que participan necesariamente tres actores: el líder, el pueblo y sus enemigos ${ }^{2}$ y que tienden a homogeneizar las identidades políticas. A contramano de estas tendencias, aquí nos proponemos mostrar que dos experiencias políticas disímiles, específicamente el peronismo en Argentina y el gaitanismo en Colombia, compartirían ciertos rasgos propios de los populismos, entendiendo a éstos como discursos caracterizados por construir identidades políticas contingentes. ${ }^{3}$ Abordaremos, pues a la constitución identitaria como un proceso histórico (esto es, mutable y susceptible de transformaciones a lo largo del tiempo), inestable y constitutivamente heterogéneo.

Cuando decimos que los populismos son discursos que construyen identidades constitutivamente heterogéneas, no sólo queremos señalar la tensión —ya introducida por Ernesto Laclau - entre la tendencia a la homogeneidad interna y a la diferenciación externa en los procesos identitarios, ${ }^{4}$ sino especialmente la heterogeneidad que se produce internamente en las identidades frente a las múltiples tensiones que las habitan al momento de articularse en un discurso populista.

Para mostrar esto, retomaremos dos aportes de los llamados estudios postlaclausianos que han avanzado en el tratamiento de las diversas maneras en que la heterogeneidad ${ }^{5}$ opera en los populismos latinoamericanos, específicamente: las consideraciones de Gerardo Aboy Carlés sobre el carácter pendular de las identidades ${ }^{6}$ y las reflexiones de Sebastián Barros

\footnotetext{
${ }^{2}$ Recientemente María Casullo ha sintetizado esta tesis, según la cual los populismos serían discursos míticos en los que participan "el líder", "el pueblo" y "el villano", el enemigo externo o "traidor interno". María Esperanza Casullo, ¿Por qué funciona el populismo? (Buenos Aires: Siglo XXI, 2019), 65.

${ }^{3}$ Ernesto Laclau, La razón populista (Buenos Aires: Fondo de Cultura Económica, 2005).

${ }^{4}$ Debido a los efectos de frontera, toda identidad está constitutivamente dividida entre su reivindicación particular (cadenas de diferencia o elementos que no logran articularse en el discurso) y un elemento que entra en articulación con otros, a partir de la mutua oposición a un "enemigo común" (cadenas de equivalencias). Por un lado, hegemonía implica entonces homogeneización de las identidades y, por el otro, tensiones o resistencias a dicho proceso, elemento que impide que la hegemonía sea concebida como una estructura totalizante y estable. La heterogeneidad es así constitutiva de los populismos.

${ }^{5}$ En términos de Laclau lo heterogéneo "no significa diferencia, dos entidades para ser diferentes necesitan de un espacio dentro del cual esa diferencia sea representable, mientras que lo que [...] estamos llamando heterogéneo presupone la ausencia de ese espacio común" Ernesto Laclau. La razón populista. op. cit., 176.

${ }^{6}$ Gerardo Aboy Carlés, "El nuevo debate sobre el populismo y sus raíces en la transición democrática: el caso argentino". Revista Colombia Internacional. N. 82 (2014): 35-44. Gerardo Aboy Carlés, "Populismo, regeneracionismo y democracia". POSTData, vol. 15, No1, (2010): 11-30.
} 
sobre los procesos de emergencia de las identidades populares en contextos de relativa estructuralidad de los discursos. ${ }^{7}$

La cuestión de la heterogeneidad ha sido clave para profundizar algunas ideas introducidas por Laclau, aun cuando esta dimensión permanece poco explorada en su propia teoría, por ejemplo: ¿qué distinciones es posible establecer entre identidades políticas e identidades populares? ¿Qué papel juegan los modos de identificación popular en los populismos? ¿Si asumimos que los populismos constituyen modos de articulación política, qué características tendría esta lógica articularia en contraste con otras posibles? Tanto Aboy Carlés como Barros van a proponer que los populismos son un tipo específico de articulación de identidades populares, las cuales sólo en determinados contextos podrían articularse "de manera populista".

Conforme con Aboy Carlés, las identidades populares básicamente son un "tipo de solidaridad política que emerge a partir de cierto proceso de articulación y homogeneización relativa de sectores que, planteándose como negativamente privilegiados en alguna dimensión de la ida comunitaria, constituyen un campo identitario común que se escinde del acatamiento sin más y la naturalización de un orden vigente". ${ }^{8}$ Nótese que las identidades así definidas, no tienen por qué ser mayoritarias, ni objetivamente subalternas, sino que se caracterizan por su oposición a un orden establecido, ya sea político, social, sexual, económico, entre otros.

El autor parte de distinguir tres tipos de identidades populares: las identidades parciales (o sin pretensión hegemónica, en las que priman las reivindicaciones particulares), las totales (que aspiran a la constitución de una unidad política homogénea, pues en ellas no hay negociaciones posibles con antagonistas o adversarios), y las identidades con pretensión hegemónica. Estas últimas son las que habilitan la emergencia de los populismos, precisamente porque su lógica de constitución identitaria busca la negociación constante de su "identidad como la conversión de los adversarios"9 al propio campo identitario. Claramente, ello no supone que los intentos de conversión de los antagonistas se realicen siempre a través del diálogo y de amistosas negociaciones, de hecho el autor señala que distintas experiencias "recurrieron a variadas formas de represión selectiva del espacio opositor". Sin embargo, lo significativo de estas identidades es que "su estrategia nunca se redujo a la conversión forzada". Por el contrario, los populismos se caracterizan por un mecanismo pendular más complejo: un modo de negociar la "tensión entre la ruptura y la conciliación del espacio comunitario, consistente en la a veces alternativa, a veces

\footnotetext{
${ }^{7}$ Sebastián Barros, "Despejando la espesura. La distinción entre identificaciones populares y articulaciones políticas populistas", en Las brechas del pueblo. Reflexiones sobre identidades populares y populismo, eds. Aboy Carlés, G., et. al. (Buenos Aires: UNGS-UNDAV Ediciones, 2013), 41-64. Sebastán, Barros, "Momentums, demos y baremos. Lo popular en los análisis del populismo Latinoamericano". POSTData, vol. 19, núm. 2, octubre, (2014): 315-344. ${ }^{8}$ Gerardo Aboy Carlés, "De lo popular a lo populista o el incierto devenir de la plebs", op. cit., 21. Resaltado propio.
}

${ }^{9}$ Ibíd., 34. 
simultánea, exclusión-inclusión del oponente del demos legítimo". ${ }^{10}$ Por ello, los límites que trazan las fronteras políticas en los discursos populistas son siempre porosos, ya que no sólo las fronteras son susceptibles de desplazamientos sino que "permiten una importante movilidad a través de ellos", ${ }^{11}$ haciendo que nuevos sectores se integren al campo identitario, que otros antes incluidos queden por fuera, entre otras posibilidades.

De modo que, para este autor, la heterogeneidad no se reduce a aquello que queda fuera de una articulación populista (en términos de Laclau, inicialmente el exterior trazado por las fronteras políticas), sino que remite a la tensión entre "particular y universal" que atraviesa al espacio articulatorio en los discursos populistas o con pretensión hegemónica. ${ }^{12}$

Por su parte, Sebastián Barros prefiere hablar de identificaciones populares para enfatizar el carácter contingente, conflictivo y relacional de todo proceso identitario. Las identificaciones populares se caracterizan (entre otros rasgos) por su potencial capacidad dislocatoria, o de subvertir un determinado orden de cosas, a través del cuestionamiento de los papeles socialmente asignados. Esta cuestión ha sido especialmente estudiada por la historiografía del peronismo, del gaitanismo y de los populismos latinoamericanos en general como la denominada quiebra de la "deferencia social". ${ }^{13}$ Ahora bien, para Barros la quiebra de la deferencia no se reduce a la mera denuncia de una exclusión material y simbólica de la parte del pueblo no reconocida legítimamente - los menos privilegiados o el pueblo en tanto plebs - sino que, además, dicha denuncia puede (en determinados contextos de relativa estructuralidad de los discursos) habilitar un reordenamiento de las posiciones sociales. De ahí su relevancia para el estudio de los populismos. Recuperando reflexiones de Jacques Rancière, Barros especifica que las identificaciones populares son "articuladas de forma populista" cuando estamos en presencia "de un discurso que pone un nombre al carácter excluyente del orden comunitario y crea retroactivamente una nueva comunidad legitima". ${ }^{14}$

En una dirección analítica similar a la de Aboy Carlés, Barros argumenta que lejos de constituir una teoría sobre la homogeneidad de las identidades políticas (como en ocasiones

\footnotetext{
${ }^{10}$ Gerardo Aboy Carlés, "El nuevo debate sobre el populismo y sus raíces en la transición democrática: el caso argentino". Revista Colombia Internacional. N 82 (2014): 40.

${ }^{11}$ Gerardo Aboy Carlés "De lo popular a lo populista ...", op. cit, 36.

${ }^{12}$ Gerardo Aboy Carlés, "Populismo, regeneracionismo y democracia", op. cit.

13 Conforme con Juan Carlos Torre lo que había acontecido durante la emergencia del peronismo era "precisamente, la quiebra de la deferencia, esto es, el fin de la aceptación del lugar que en un sistema normativo o en un orden hegemónico tienen los actores sociales involucrados". Juan Carlos Torre, "Interpretando (una vez más) los orígenes del peronismo", en María M. Mackinnon y Mario A. Petrone (Comp.) Populismo y neopopulismo en América Latina. El problema de la Cenicienta. (Buenos Aires: EUDEBA, 1999 [1989]), 197. Posiblemente quien más se detuvo en el tratamiento de la crisis de deferencia en la historiografía sobre el gaitanismo, fue Herbert Braun. En su interpretación del 9 de abril, la deferencia juega un papel similar al que Torre le dio en su análisis del peronismo. En definitiva tanto el gaitanismo en Braun como el peronismo en Torre, no lograron resolver la crisis de deferencia habitual que caracterizaba a la vida y a las prácticas políticas de cada país. Ver: Herbert Braun, Mataron a Gaitán. Vida pública y violencia urbana en Colombia. (Bogotá: Editorial Aguilar, 2008 [1985]).

${ }^{14}$ Sebastián Barros, “Despejando la espesura...”. op. cit., 55.En adelante, los énfasis son míos.
} 
erróneamente se la presenta), la perspectiva de Ernesto Laclau sobre el populismo propone un abordaje de lo heterogéneo que va desde una "heterogeneidad radical (dos entidades que no comparten un espacio común de representación) hasta el resto de heterogeneidad ineliminable que constituye la distinción de toda particularidad (su pérdida supondría la desaparición de la diferencia)". ${ }^{15}$ En la distinción de diversos niveles de heterogeneidad que estarían presentes en la teoría laclausiana, ${ }^{16} \mathrm{el}$ investigador argentino añade otro nivel que no está claramente identificado en Laclau "y que es aquel entre las diferencias articuladas y el momento hegemónico articulante [...]. En este nivel de heterogeneidad se juega la instancia que define el tipo de unidad que adquirirá una articulación política". ${ }^{17}$

Precisamente en ese último nivel de heterogeneidad nos interesa pensar aquí. Pues esa heterogeneidad supone que dentro de un mismo campo identitario, llamado peronismo y gaitanismo en este caso, es posible dar cuenta de conflictos y oposiciones internas; y que tales tensiones no siempre derivan en el simple abandono de ese campo o en la mera inclusión de los sectores críticos en el discurso de los adversarios. Por el contrario, argumentamos que dichas heterogeneidades y tensiones (articuladas en los discursos populistas por cierto) son una dimensión característica de los procesos identificatorios que habilitan los populismos.

Nos proponemos entonces ilustrar algunas de estas tensiones y heterogeneidades a través de sucesivos actos o procesos identificatorios ${ }^{18}$ de dos figuras mediadoras y especialmente controversiales durante la gestación del peronismo y del gaitanismo: Cipriano Reyes y J. A. Osorio Lizarazo. Ambos tuvieron papeles protagónicos en momentos fundacionales de los movimientos y en circunstancias políticas concretas, como la nacionalización o la construcción a gran escala de los movimientos, se opusieron y/o cuestionaron a Perón y a Gaitán, sin renunciar al campo identitario signado por los líderes como peronista y gaitanista. Resaltamos que los nombres que asumieron los movimientos colocaron en primer plano a los líderes políticos, pues precisamente Reyes y Osorio Lizarazo lideraron batallas por el sentido de los movimientos y, el primero en especial, por la paternidad del peronismo. Como veremos, las estrategias de estas figuras fueron distintas. Reyes, enfatizó que el nombre peronismo no remitía a la verdadera identidad política que emergió el 17 octubre de 1945, sino a otra deliberadamente borrada por Perón: el laborismo. Mientras que Osorio Lizarazo apeló al mismo significante (gaitanismo) para disputarle a

\footnotetext{
${ }^{15}$ Sebastián Barros, "Polarización y pluralismo en la teoría de la hegemonía de Ernesto Laclau". Latinoamérica. N. 67/2. Octubre (2018): 28.

${ }^{16}$ Un primer nivel de heterogeneidad remite a la exterioridad constitutiva, la cual está dada "por la frontera antagónica que constituye una cadena de equivalencia" y "algo externo a ella que al mismo tiempo niega su plenitud y es condición de su existencia". Un segundo nivel es el de las diferencias, que "reside en el resto de particularidad persistente entre las propias diferencias articuladas en una cadena equivalencial determinada". Y un tercer nivel, radical, refiere a "los elementos que no son diferencias en tanto no comparten un espacio de representación simbólica. El nivel de la no-diferencia”. Sebastián Barros, Ibíd., 67.

${ }^{17}$ Ibíd., 67.

${ }^{18} \mathrm{Al}$ seguir el rastro a los sucesivos actos de identificación de estas figuras se propone focalizar el estudio de las identidades políticas bajo la idea de un proceso susceptible de cambios y transformaciones a lo largo del tiempo, es decir, contingente o no definible de una vez y para siempre.
} 
Gaitán la verdadera esencia del movimiento, una que para él debía ser intransigentemente revolucionaria.

Lo sugestivo de las agudísimas críticas que por momentos esgrimieron estos actores, es que en ellas persiste una férrea resistencia a la heterogeneidad que comenzaba a teñir a los movimientos políticos al momento de nacionalizarse. En los casos que analizaremos a continuación este no es un dato menor, pues los enfrentamientos con los líderes y con sectores recientemente integrados a los movimientos — como los radicales renovadores en el seno del laborismo argentino o los liberales en el seno del gaitanismo colombiano- derivaron en violentos intentos de cierre de las fisuras internas, como la reclusión de Reyes o el auto-exilio de Osorio Lizarazo. Precisamente por ello nos interesa trabajar con estas figuras, en ocasiones consideradas por la historiografía sobre el peronismo y sobre el gaitanismo como disidentes $\mathrm{u}$ opositores $\mathrm{y}$, en otras, como mitos vivientes de los movimientos.

Sin la pretensión homologar experiencias que por cierto son distintas, tomaremos a cada una como punto de comparación con la otra, ${ }^{19}$ pues entendemos que ello nos permitirá sortear algunos lugares comunes antes referidos en los estudios sobre populismos. Lo interesante del contraste entre peronismo y gaitanismo, en este punto, es que el nivel de heterogeneidad que nos interesa ilustrar (interno al campo identitario) no se limita a aquellas experiencias populistas que construyeron gobiernos nacionales, ni a las características propias de un tipo de liderazgo, o a las políticas públicas implementadas por los líderes en el Estado, sino que se relaciona fundamentalmente con las inscripciones identitarias producidas durante los años de emergencia de los movimientos; las cuales, en ocasiones, guardaron una carga de sentido de tal magnitud que sus modos identificatorios se volvieron, en otras coyunturas (como la construcción de los movimientos a gran escala), "innegociables".

Finalmente, conviene precisar la noción de mediación que aquí utilizamos y su aporte para el estudio de los populismos y los procesos de identificación política. En primer lugar, la idea de mediación subraya una orientación introducida por una serie de trabajos recientes que han reparado en las prácticas y acciones de las segundas líneas de los movimientos populistas; en contraste con los estudios centrados en la descripción de estilos de liderazgo como unos basados en relaciones de poder verticales y directas (o sin mediaciones) entre un líder carismático y las masas. Como ha advertido Raanan Rein, de no haber sido por el establecimiento de "vías alternativas de mediación para movilizar el apoyo popular" sería incomprensible "el legado duradero del populismo en América Latina a la hora de "modelar

\footnotetext{
19 Enfoque metodológico construido para el análisis de experiencias políticas disímiles. Más que una comparación en sentido duro, ello supone analizar formas de producción social de sentidos sobre lo político, especificidades y contingencias propias de cada experiencia histórica, tratando a cada una de ellas como un punto de comparación con otras. Las operaciones analíticas se orientan a identificar aspectos controversiales y significativos de cada proceso, los cuales resultarían especialmente perceptibles desde dichos puntos de comparación. Sobre este punto ver: Ana Lucía Magrini “Apuntes metódicos para una historia y política como significación”, en Métodos: aproximaciones a un campo problemático. Farrán, Roque, et. al. (Buenos Aires: Prometeo, 2018), 253-286.
} 
la arena política' y de imbuir nuevos significados en el concepto de la ciudadanía". ${ }^{20}$ De modo que, indagar el papel que desempeñaron las segundas líneas se torna una cuestión crucial a la hora de comprender lo perdurable del peronismo, del gaitanismo y de los populismos en general.

En segunda instancia, la categoría de mediación desnuda una falsa idea persistente en algunos estudios centrados en las estrategias de comunicación de los populismos. Ese falso supuesto reduce los procesos de comunicación de los movimientos populistas a unos de tipo directos - o nuevamente sin mediaciones - En general, estos enfoques tropiezan con una dificultad evidente al intentar caracterizar la enunciación de los líderes y la recepción "de las masas". Instancias políticas y comunicativas que, además, suelen pensarse como autotransparentes o bajo la idea de un reflejo (es decir, que aquello que se enuncia es equivalente a lo que se recepta). El problema de estas aproximaciones radica en que suponen la transparencia del lenguaje, cuando en efecto este constituye un campo minado de interpretaciones, prácticas e intervenciones que hacen de él un fondo opaco y contaminado. Por otra parte, como la teoría de las mediaciones y de la comunicación como proceso ha venido señalando, desde hace ya varias décadas, ${ }^{21}$ los receptores tampoco no son pasivos, intervienen, resemantizan o resignifican discursos $y$, con frecuencia, se convierten "enunciadores" de otros discursos políticos.

En tercer lugar, la noción de mediación que proponemos dialoga con la historia intelectual. Pues nuestros "mediadores" son actores políticos concretos que produjeron obras muy variadas (biografías, autobiografías, poemas, novelas, ensayos, crónicas, artículos periodísticos, entre otros géneros), a través de las cuales intentaron intervenir en el campo intelectual y cultural construyendo sus propias interpretaciones sobre el peronismo y el gaitanismo, algunas de ellas especialmente críticas respecto a las elaboradas por los líderes. En este sentido, al focalizar en cómo estas figuras (en tanto intérpretes del peronismo y del gaitanismo), disputaron sentidos sobre los movimientos, los líderes y el papel que ellos mismos desempeñaron en estos, procuramos tensionar el binomio entre "campo político y campo intelectual" para abordar ambos articuladamente. ${ }^{22}$ En definitiva, trabajando con actores significativos y controversiales en las opacidades de la discursividad de dos

\footnotetext{
${ }^{20}$ Raanan Rein, "Repensando el populismo en América Latina: el caso argentino" en: Entre viejos y nuevos populismos, Carreras Doallo, X. y Mateo, G. Comps. (Ebook: Editorial CICCUS, 2019), 103.

${ }^{21}$ Ejemplo de ello son los pioneros trabajos de Jesús Martín-Barbero, De los medios a las mediaciones. Comunicación, cultura y hegemonía(Bogotá: Convenio Andrés Bello, 2003). Jesús Martín-Barbero, Comunicación masiva, discurso y poder (Quito: Editorial Época, 1978). Para un estudio de los posibles cruces y puntos de contacto entre la teoría política del discurso y la teoría de las medicaciones, ver: Ana Lucía Magrini y María Virginia Quiroga, "Comunicación y política en el cruce de las perspectivas de Jesús Martín-Barbero y de Ernesto Laclau". Studia Politicae, No 41, otoño (2017): 89-104.

${ }^{22}$ Son ineludibles aquí los aportes metodológicos de Carlos Altamirano en torno a la historia intelectual, y trabajos empíricos específicos en cada país, entre ellos, el de Federico Neiburg en Argentina y Mónica Zuleta Pardo. Carlos Altamirano, Para un programa de historia intelectual y otros ensayos. (Buenos Aires: Siglo XXI, 2005). Federico, Neiburg, Los intelectuales y la invención del peronismo. (Buenos Aires: Alianza Editorial, 1998). Mónica, Zuleta Pardo, La voluntad de verdad de Colombia: una genealogía de las ciencias sociales profesionales. (Bogotá: Universidad Central, 2011).
} 
populismos latinoamericanos proponemos analizar sus trayectorias, identificaciones, representaciones e interpretaciones sobre los movimientos como actos políticos en sí.

\section{“El héroe no reconocido"... o cómo Cirpiano Reyes construyó su identidad política}

Difícil de posicionar dentro de las interpretaciones peyorativas y las claramente apologéticas sobre el peronismo, frecuentemente citada como fuente y poco explorada en términos de la mirada que allí se construye sobre el peronismo, la perspectiva de Cipriano Reyes (y el modo de identificarse con ese discurso) fueron durante muchos años inaudibles tanto en el campo político como en el intelectual. Ciertamente, fue Juan Carlos Torre, quien a finales de los años setenta proporcionó nuevos lentes analíticos para entender a la tradición de que la que Reyes provenía, el laborismo. ${ }^{23} \mathrm{Su}$ argumento desplazó el debate sobre el peronismo hacia la pregunta por las identidades políticas, específicamente, hacia las relaciones que se establecieron entre Perón y el movimiento obrero. Pese a haber deconstruido la explicación clásica (de Gino Germani) ${ }^{24}$ sobre los orígenes del movimiento, la conclusión a la que llegó Torre no distó mucho de otras miradas que habían insistido en la docilidad de los gremios que adhirieron al llamado de Perón, ${ }^{25}$ en la interpretación del peronismo como una oportunidad perdida, la oportunidad de haber conformado un partido obrero autónomo (como el laborista británico) y la de constituir una democracia pluralista. ${ }^{26}$ Todo ello, sumado a la idea de que el peronismo constituía un fenómeno populista en sentido autoritario. ${ }^{27}$

Dicho sin preámbulos, con otras variables explicativas, con nuevas fuentes documentales (como las actas del Comité Central Confederal de la CGT) y con una nueva problematización del fenómeno (las identidades políticas), el autor no alteró la interpretación dominante sobre el peronismo. Ciertamente este no es "un problema" del trabajo de Juan

\footnotetext{
23 Juan Carlos Torre, La vieja guardia sindical y Perón. Sobre los orígenes del peronismo. (Buenos Aires: Editorial Sudamericana - Instituto Torcuato Di Tella, 1990).

${ }^{24}$ Ver Gino Germani, Política y sociedad en una época de transición. De la sociedad tradicional a la sociedad de masas. (Buenos Aires: Paidós, 1962).

${ }^{25}$ En este punto la interpretación de Torre se aproxima a la de Hugo Del Campo, quien sostuvo "que el peronismo se fue construyendo a partir de una interacción entre Perón y lo dirigentes sindicales" (Hugo Del Campo, Sindicalismo y peronismo. Los comienzos de un vínculo perdurable. (Buenos Aires: Siglo XXI, 2005 [1983]), 16. Lo que resultaba problemático de esas relaciones era cómo había sido posible que los trabajadores organizados "hayan abandonado su tradicional prescindencia política para apoyar la candidatura de Perón”. Ibíd., 15.

${ }^{26}$ En este orden de ideas, es perceptible la relación con la interpretación que Halperín Donghi formuló en el famoso número 7-8 de la revista Contorno. Para el historiador argentino, "la historia del peronismo no necesita ser la historia de una desvanecida oportunidad revolucionaria para ser en efecto la de una oportunidad perdida" (Tulio Halperín Donghi. "Del fascismo al peronismo", en Argentina en el callejón. (Buenos Aires: Ariel, 1994), 53. Originalmente ensayo publicado en Contorno № 7-8, Buenos Aires, [1956].

${ }^{27} \mathrm{Si}$ bien el autor recupera la conceptualización del populismo formulada por Alain Touraine, para quien en América Latina los populismos consistían en políticas nacional-populares, en su análisis sobre el origen del movimiento Torre termina subrayando que "estamos ante un proceso de democratización por vía autoritaria." Juan Carlos Torre, "Interpretando (una vez más) los orígenes del peronismo", en Populismo y neopopulismo en América Latina. El problema de la Cenicienta. Mackinnon, M. y Petrone, M. Comp. (Buenos Aires: EUDEBA, 1999 [1989]), 188. Cursivas en el original.
} 
Carlos Torre, el cual ha sido considerado uno de los aportes más lúcidos sobre sus orígenes y quien formuló (en un texto más reciente escrito en colaboración con Elisa Pastoriza), ${ }^{28}$ una interpretación ejemplar ${ }^{29}$ sobre los primeros años peronistas. El señalamiento, constituye en realidad - y esto es lo verdaderamente problemático—-, una tendencia general en los estudios sobre peronismo (y populismo), caracterizados por el predominio de "miradas subjetivistas", esto es, de posicionamientos apologéticos o claramente orientados a descalificar dicha experiencia política. ${ }^{30}$

Con otros objetivos, intentaremos aquí volver al primer gesto analítico con el que Torre interrogó el peronismo, las identidades políticas. Aunque, parafraseando a Sebastián Barros,${ }^{31}$ no dirigiremos la mirada hacia el Estado sino hacia la forma singular que tomaron sucesivos actos identificatorios de un actor fundacional y especialmente crítico, Cipriano Reyes.

Oriundo de Lincoln, provincia de Buenos Aires, Cipriano Reyes (1906-2001) fue contorsionista de circo, aprendiz de vidriero, pescador, trabajador rural, panadero, mucamo valet, ensayista, periodista, poeta, obrero de la industria de la carne y líder sindical. Luego de recorrer el país como linyera — período que el mismo describe como una experiencia de trotamundos - se estableció en la localidad bonaerense de Berisso, donde permaneció la mayor parte de su vida y donde fundó el Sindicato Autónomo de Obreros de la Industria de la Carne y Afines.

Fue uno de los organizadores de la multitudinaria movilización obrera del 17 de octubre convocada para exigir la liberación de Perón. Luego del éxito de la extensa jornada y del llamado a elecciones para febrero de 1946, Reyes junto con otros dirigentes sindicales fundaron el Partido Laborista, plataforma política que llevó a Perón a la presidencia y al

\footnotetext{
${ }^{28}$ Juan Carlos Torre y Elisa Pastoriza, "La democratización del bienestar" en Nueva Historia Argentina. Torre J. C. (Dir.) (Buenos Aires: Sudamericana, 2002), 257-313.

${ }^{29}$ Conforme con Acha y Quiroga, un modelo ejemplar remite a una interpretación que domina "un territorio complejo al diseñar una pequeña 'filosofía de la historia' para el período o tema que trata. Lo fundamental es que regula el orden de validaciones, y por lo tanto, es adoptado como presupuesto de las 'nuevas investigaciones'. Sus contenidos se hacen estructura prediscursiva, en el sentido que es condición de enunciación de otros discursos. Solo entonces se hace invisible como modelo ejemplar, y multiplica su eficacia." Omar Acha y Nicolás Quiroga, El hecho maldito. Conversaciones para otra historia del peronismo. (Buenos Aires: Prohistoria. 2012), 24.

${ }^{30}$ En otro lugar me detuve en explicitar la trayectoria de variadas interpretaciones sobre el primer peronismo, gaitanismo, populismo y Violencia(s), producidas en Argentina y Colombia, durante la segunda mitad del siglo XX. Un hallazgo de esa pesquisa (de orden más historiográfico y en sintonía con la nueva historia intelectual) fue que si bien eran perceptibles tres posicionamientos, a saber: las explicaciones con pretensión de verdad científica producidas por las ciencias sociales (textos a los que llamé narrativas objetivistas), las intervenciones de actores directamente involucrados en los acontecimientos (quienes produjeron ensayos y testimonios que categoricé como narrativas subjetivistas) e intelectuales de variados campos disciplinares que ensayaron miradas más "pluralistas" (a las que llamé polifónicas); desde un análisis diacrónico y de largo alcance, fueron las representaciones "subjetivistas" aquellas que primaron durante todo el período en ambos países, contaminando o fundiéndose de diversas maneras en las otras. Véase: Ana Lucía Magrini, Los nombres de lo indecible. Populismo y Violencia(s) como objetos en disputa. Un estudio comparado del peronismo en Argentina y el gaitanismo en Colombia. (Buenos Aires, Prometeo, 2018).

${ }^{31}$ Sebastián Barros, "Momentums, demos y baremos..." op. cit.
} 
propio Reyes al Congreso Nacional. En mayo de ese año, Perón llamó a la unidad de todas las fuerzas que se aglutinaban en el peronismo, disolvió el Partido Laborista y creó el Partido Único de la Revolución, posteriormente denominado Partido Peronista. Reyes se opuso a la disolución del laborismo. En 1947 sufrió un atentado en el que murió su chofer y en 1948, una vez finalizado su mandato y ya declarada la ilegalidad del laborismo, fue acusado de organizar un complot para derrocar a Perón, razón por el cual fue encarcelado hasta 1955. Ese año fue liberado y, en 1957, se opuso a la denominada Revolución Libertadora e intentó reorganizar el Partido Laborista con miras a restituir la Constitución de 1949, sancionada durante el primer gobierno peronista.

Desde la creación del Partido Laborista, Reyes resistió a la inclusión de quienes habían estado por completo ausentes en la crítica jornada de octubre del 45 . No podía "abrazar como amigos" a quienes habían sido "bastoneros" de toda la "corriente opositora [a Perón] y antiobrera”, entre 1943 y $1945 .{ }^{32}$ Más allá de sus señalamientos respecto a los nuevos integrantes repentinamente conversos al laborismo, un sector de la UCR (Junta Renovadora) se unió a la plataforma política que finalmente ganó las elecciones y conformó el nuevo gobierno, en 1946.

Al poco tiempo de la victoria electoral, el 23 de mayo de 1946, Perón ordenó caducas “en toda la República las autoridades partidarias de todas las organizaciones que pertenecen al movimiento peronista” y encargó "a los camaradas legisladores que forman las autoridades [...] la organización de todas las fuerzas peronistas como Partido Único de la Revolución Nacional". ${ }^{33}$ La respuesta de Reyes no se hizo esperar y pocos días del comunicado presidencial transmitido por cadena nacional, le envió una carta a Perón cuyo encabezado no podía ser más directo: "Señor Presidente electo de la República por el Partido Laborista, general Juan D. Perón":

"Hace pocas horas $[\ldots]$ usted termina de romper $[\ldots]$ con el laborismo, a través de un 'ordeno y mando', como si lo hubiera hecho el zar de Rusia o el mismo Calígula, emperador de Roma.

Desconoce el movimiento que lo llevó al poder porque teme que el mismo el exija la realidad de ese mundo mejor que le hemos prometido al pueblo y al país [...]. Ahora está en la cima, y desde allí arroja al precipicio a los amigos que lo ayudaron a subir. [...], usted, señor presidente, desvió el cauce de la revolución popular y nacional [...], convirtiendo a sus aláteres en un conglomerado amorfo, sometido al servilismo [...]. De mi parte, hágole saber que me incorporaré a mi banca de diputado nacional, sosteniendo lo que usted, señor presidente, arrojó a la clandestinidad: el laborismo." ${ }^{34}$

\footnotetext{
${ }^{32}$ Cipriano Reyes. La farsa del peronismo... op. cit., 13-14.

${ }^{33}$ Discurso de Perón, 23 de mayo de 1946, cadena nacional. En: Ibíd., 180-183.

${ }^{34}$ Carta de Cipriano Reyes a Perón, 27 de mayo de 1946. En: Ibíd., 183-184. Resaltado propio. En adelante, las cursivas son mías.
} 
Algunos compañeros y amigos de Reyes intentaron persuadirlo de dejar las críticas a Perón a un lado y, en pos de la unidad del movimiento, aceptar "la peronización del laborismo". "Escupí para otro lado, Cipriano, y verás que todo va a salir bien”; "debemos sacrificarnos por la unidad del movimiento”; "Olvidate de eso, Cipriano, y aprovechemos para estar todos juntos", ${ }^{35}$ son algunos consejos, que él mismo recuerda y a los que sólo oiría inicialmente, durante la constitución del partido, luego de su disolución ya no podría aceptar la completa desaparición del laborismo.

El líder sindical escribió tres libros: ¿Qué es el laborismo? Publicado en 1946, texto en el que formula duras críticas a los llamados a la unidad del Partido Único; ${ }^{36}$ Yo hice el 17 de octubre, autobiografía publicada en 1973, el mismo año en que se produjo el retorno definitivo de Perón a la Argentina, luego de un exilio de más de una década; ${ }^{37}$ y La farsa del peronismo, ${ }^{38}$ libro que vio la luz pública en 1987, en la coyuntura del fallido intento de golpe de Estado a Raúl Alfonsín del 15 abril de ese año, entonces ya había transcurrido el retorno de la democracia aunque bajo la constante amenaza de las Fuerzas Armadas.

A lo largo de estas obras el líder del gremio de la carne fue radicalizando su mirada sobre el peronismo y construyendo su identidad política desde una identificación, positiva y negativa al mismo tiempo, con elementos sustanciales de este discurso. Más allá de la diferencia de géneros desde los que Reyes cuenta su historia en cada uno de sus libros (el ensayo en el primero, la autobiografía en el segundo y la crónica en el tercero), en ellos, el melodrama constituye un modo de tramar específico que hace posible articular, la épica con el romance; ${ }^{39}$ esto es, las dimensiones más íntimas y cotidianas de su vida (sucesos significativos a nivel personal, por ejemplo, los sacrificios de una vida como peón de campo y como obrero en la ciudad, la injusticia y la humillación frente a figuras de autoridad, su lucha gremial, la pérdida de sus hermanos,${ }^{40}$ su desempeño como diputado nacional entre 1946 y 1948, la cárcel y su liberación), con los cambios políticos de orden más abstracto (el

\footnotetext{
${ }^{35}$ Ibíd., 15 y 18.

${ }^{36}$ Cipriano, Reyes, ¿Qué es el laborismo? (Buenos Aires: Ediciones R.A, 1946).

${ }^{37}$ Cipriano, Reyes, Yo hice el 17 de octubre. (Buenos Aires: Editorial G-S, 1973).

${ }^{38}$ Cipriano Reyes, La farsa del peronismo... op. cit.

${ }^{39}$ Sigo aquí algunas ideas elaboradas por Daniel James, Doña María: historia de vida, memoria e identidad política. (Buenos Aires: Manantial, 2004).

${ }^{40}$ Reyes no profundiza en este punto. Sin embargo, a través de testimonios de otros protagonistas es posible advertir la relevancia de esas pérdidas. En la historia de vida sobre María Roldán que escribió Daniel James, la líder laborista se refiere a la dramática escena del entierro del hermano de Cipriano Reyes, Doralio, quien cayó muerto en un enfrentamiento a tiros con comunistas en vísperas del 17 de octubre. Al entierro había asistido Perón. Recientemente, en una nota periodística, Dora Roldán, hija de María, expresó que, en el entierro de Doralio, Perón llamó aparte a María y le pidió que no mencione que dos días antes del acto comunista (que los laboristas se proponían romper), "Perón reunió a [su madre y], a otra gente de Berisso [...] les mostró [unos] revólveres y les [dijo:] pero tiren para asustar, para dispersar, no tiren al cuerpo, no hagan macanas!". La jugada salió mal, un infiltrado comunista había alertado al PC, y lo que se suponía debía ser sólo una amenaza se convirtió en un enfrentamiento armado. Dora Roldán, "La olvidada historia de la mujer que lideró el 17 de octubre en Berisso", Pregoneros gráficos, Mendoza, 18 de Octubre, 2018.
} 
17 de octubre, la formación del Partido Laborista, el primer gobierno peronista y la dictadura militar que derrocó a Perón). ${ }^{41}$

En su autobiografía, Cipriano Reyes reconstruye críticamente el mito fundacional del peronismo desde las voces de un sector de sindicalistas que se movilizaron aquella jornada, que formaron el Partido Laborista en 1946, que no superaron las tensiones al interior del partido - sustancialmente debido a la incorporación al peronismo de radicales renovadores (UCR-Junta Renovadora) - y que perdieron en el juego de la política tradicional. Su testimonio involucra un relato del yo en que el propio Reyes se auto-representa como un héroe no reconocido, cuya acción en la jornada de octubre del 45 fue tergiversada, tanto por la historia oficial del peronismo como por la versión construida por el antiperonismo. Para el líder sindical, el 17 de octubre "el pueblo pueblo" (la plebs, o la parte del pueblo no reconocida como miembros legítimos de la comunidad), impulsado "por todo ese hambre y sed de justicia" deseaba producir "el cambio en profundidad [...] con una revolución nacional y popular [...] en el camino de un mundo mejor". El 17 de octubre "fue la marcha de los postergados, de los perseguidos de los que venían y vienen cargando el peso de la injusticia social". ${ }^{42}$ Hasta aquí Reyes reproduce prácticamente la mirada oficial sobre el acontecimiento y ciertamente se opone a la amplitud de interpretaciones producidas por el heterogéneo arco antiperonista. Recordemos que algunas de ellas habían demonizado a quienes protagonizaron aquella jornada y habían negado que Perón se encontrara preso, argumentando que en realidad el líder se había auto-recluido. ${ }^{43}$

La oposición con el antiperonismo se introduce, en la autobiografía, a través de una interesante referencia cruzada: ${ }^{44}$ la discusión con Germán Arciniegas, una destacada figura intelectual, contemporáneo de Gaitán y exponente del pensamiento liberal colombiano y americanista, quien además había contribuido a la consagración de Osorio Lizarazo como escritor. ${ }^{45}$ Antes de la emergencia del peronismo, Arciniegas había sido canciller de la Embajada de Colombia en Buenos Aires y luego del derrocamiento de Perón regresó al país, “en calidad de 'viajero democrático' a brindarle sus mejores expresiones al gobierno de facto de Aramburu". ${ }^{46}$ En aquella oportunidad Reyes escribió una carta que fue publicada en $E l$

\footnotetext{
${ }^{41}$ Con el derrocamiento de Perón, en 1955, Reyes fue liberado y recibido personalmente por Eduardo Lonaridi (presidente de facto), como "mártir de la libertad". Cipriano Reyes. La farsa del peronismo... op. cit., 170.

${ }^{42}$ Cipriano Reyes. Yo hice el 17 de octubre... op. cit., 93.

${ }^{43}$ Para un estudio de la heterogeneidad del antiperonismo y cómo, en lo cultural, ese posicionamiento político "se complementó con una descripción de las masas peronistas como incultas y proclives a la violencia, denigradas con estereotipos clasistas, racistas y sexistas", ver: Jorge Nállim, Las raíces del antiperonismo. Orígenes históricos e ideológicos (Buenos Aires: Capital Intelectual, 2014).

44 Nos referimos a las representaciones sobre Colombia que circulan en el testimonio de Reyes, y viceversa, las representaciones sobre Argentina perceptibles en Osorio Lizarazo.

45 Oscar Calvo Isaza, "Biografía de nadie: José Antonio Osorio Lizarazo (1900-1964)”. (Tesis de Maestría, Escuela Nacional de Antropología e Historia. Ciudad de México, 2005), 89.

${ }^{46}$ Cipriano Reyes. Yo hice el 17 de octubre... op. cit. 249. El fugaz gobierno de Eduardo Lonardi había sido derrocado por un golpe interno que lo había desplazado, e impuesto a Pedro Eugenio Aramburu en la presidencia. Con ese desplazamiento se intensificó la cacería de funcionarios peronistas, el extremismo y el
} 
Laborista, en la que arremete contra las acusaciones que el colombiano realizó en su libro, Entre la libertad y el miedo. En esa obra, Arciniegas argumenta que el peronismo fue una dictadura y una forma de fascismo aunque con estilo propio, que había trascendido las fronteras nacionales y se había propagado por América Latina. ${ }^{47} \mathrm{El}$ americanista presenta a Reyes como un antiguo rompehuelgas y colaborador de Evita. En la versión del intelectual colombiano, ambos, el 17 de octubre alentaron la producción de un acontecimiento casi diabólico, comparable a la marcha sobre Roma.

"Con habilidad maravillosa, los amigos de Perón, entre ellos Cipriano Reyes, amigo sobre todo de Evita Duarte, ven que ha llegado la hora del peronismo. Se van a los frigoríficos, a las fábricas, a los barrios bajos, y le alumbran al pueblo la toma del poder. '¡Alpargatas sí! ¡Libros no!' ‘¿Queremos a Perón!’ [...]. Así nació la gran marcha de los descamisados sobre Buenos Aires. Algo diabólicamente superior a la marcha de las camisas negras sobre Roma" ${ }^{\prime 4}$.

Al respecto Reyes insiste en su poco audible crónica de los acontecimientos, en la que Eva Perón no tuvo participación alguna durante el 17 de octubre. Pero si Arciniegas se atreve a cruzar la mirada y a definir el peronismo, el líder del gremio de la carne también construye una mirada cruzada sobre Colombia, sus trabajadores y el cinismo de sus intelectuales que, como Arciniegas, le dedican un libro a los "campesinos anónimos de Colombia” y crean "una leyenda negra" sobre los trabajadores argentinos. ${ }^{49}$

\footnotetext{
desquite de la política de desperonización, denunciada incluso por algunos intelectuales antiperonistas. Ver, por ejemplo, Mario Amadeo, Ayer, hoy y mañana. (Buenos Aires: Ediciones Gure, 1956), 139.

${ }^{47}$ El texto fue censurado en Colombia, publicado por primera vez, en su versión en inglés, en 1951 en Estados Unidos. Su primera edición en español apareció en 1952, en México, cuando Reyes se encontraba aún en la cárcel, y en 1956 fue reeditado en la Argentina. En esa última edición se incluyeron algunos acontecimientos producidos con posterioridad a la primera publicación del libro, como el derrocamiento del gobierno de Laureano Gómez y la instauración del gobierno del Gral. Rojas Pinilla en Colombia. En Argentina, dos hechos habían modificado rotundamente la experiencia histórica del país, la muerte de Eva Perón y la caída del peronismo. En torno al peronismo argentino y al rojismo colombiano, dirá Arciniegas: “[e]l peronismo está muerto pero no enterrado y la filosofía que Perón y Evita divulgaron por América se reproduce en otros países. Parece anacrónico, y lo es, que el General Rojas Pinilla proclame en Colombia en junio de 1956 la 'tercera posición' e implante en el país el mismo régimen de prensa que fue característico en la Argentina." Germán Arciniegas, Entre la libertad y el miedo. (Buenos Aires: Editorial Sudamericana, 1956 [1951]), 19.

${ }^{48}$ Germán Arciniegas. Ibíd., 54-55.

${ }^{49}$ Carta abierta Germán Arciniegas, El Laborista, 15 de junio de 1956. En: Cipriano Reyes. Yo hice el 17 de octubre... op. cit.
} 
“Diga señor Arciniegas, [...] cuándo fui 'camorrista'. Ese insulto lo arroja no contra mí sino contra los campesinos anónimos de Colombia que no hicieron de la libertad atrayente latiguillo de conferencias en salones alfombrados, sino bandera que se defiende con el arma al brazo [...]. Yo lo invito a que pruebe un solo hecho que pueda justificar la calificación. $E l$ señor Arciniegas deberá aceptar que los guerrilleros colombianos a quienes dedica su libro fueron o son bandoleros u hordas de asesinos, coincidiendo con la propaganda de sucesivas dictaduras para que yo comenzara a probarme el sayo". ${ }^{0}$

Precisamente los mismos puntos que trazan el debate con Arciniegas sobre el 17 de octubre, constituyen los aspectos de tensión con la versión oficial del peronismo sobre aquella jornada. Desde la mirada oficial, Eva Perón y la Confederación General del Trabajo (CGT) habían tenido un papel protagónico en el desarrollo de los acontecimientos. ${ }^{51}$ Respecto a Evita, Reyes apela a la cautela para no proporcionar una imagen negativa de quien considera una verdadera "abanderada de los humildes" y de quien "nadie puede poner [...] en tela de juicio [su] esfuerzo y el incesante anhelo [...] de ensanchar el camino hacia un mundo más feliz", ni cuestionar "su inmensa tarea en favor de los [...] desposeídos, su inmenso amor a los niños, su grandeza espiritual, su fe al servicio de las más nobles causas humanas, como así mismo su espíritu abierto y combativo". ${ }^{2}$ Sin embargo, el líder sindical no puede olvidar los sucesos del 45 en los que, insiste, Eva Perón no pudo tener participación alguna, "ya que ella ni siquiera, entonces, había tenido contacto con las bases o con los dirigentes en la organización de ese gran movimiento, por la liberación del coronel Perón". 53

Por otra parte, conforme con Reyes, tampoco la CGT tuvo cuota de colaboración durante el 17 de octubre. En realidad, para él, la central obrera entorpeció los preparativos (haciendo correr la falsa noticia de que Perón no estaba detenido, por ejemplo). ${ }^{54}$ Por si fuera poco, una vez liberado Perón, la CGT se plegó al paro nacional del día 18 (solicitado por Perón a los trabajadores en su famoso discurso del 17 de octubre) ${ }^{55}$ y quedó, con

${ }^{50}$ Ibíd., 251.

${ }^{51}$ Ver, por ejemplo, Ángel Perelman, Cómo hicimos el 17 de octubre. (Coyoacán. Buenos Aires, 1961).

${ }^{52}$ Cipriano Reyes. Yo hice el 17 de octubre... op. cit., 252.

${ }^{53}$ Ibíd.: 246.

54 Cipriano Reyes argumenta que se trató de un falso rumor que difundió el 15 de octubre un dirigente del gremio del calzado, como estrategia (de la CGT) para boicotear la huelga que los gremios autónomos estaban coordinando para el día 16.

55 Juan Carlos Torre proporcionó una lucida interpretación sobre este punto. Para Torre, la diferencia de un día entre la declaración de huelga de la CGT y la realización de la movilización no representa, ni la ausencia total de la central obrera en el 17 de octubre (la tesis de Reyes), ni su participación efectiva (tesis oficial), pues "la CGT no era entonces [...] la entidad representativa que sería más tarde; por lo que su falencia no debe ser vista como si entrañara la del conjunto de las organizaciones obreras. [...] la preparación y la canalización de las organización obrera estuvo a cargo de varios sindicatos, federados y autónomos, que actuaron en la emergencia como dirección alternativa a la CGT. [...]. En esa hora crítica, ella sirvió para comunicar a los sindicatos que estaban en estado de alerta desde el 15, y a los trabajadores, en general, que formaban parte de un vasto 
posterioridad, a cargo de las conmemoraciones y de los festejos oficiales. ${ }^{56}$ Bajo la mirada de Reyes, ciertamente el 17 de octubre tuvo una cuota de espontaneidad en cuanto las multitudes se fueron sumando a las caravanas de obreros movilizados pero esa espontaneidad se produjo gracias una fuerte dosis de planificación, la suya propia y la de trabajadores y trabajadoras que se abocaron a esa tarea sin el apoyo de figuras de la políticas tradicional o de la central obrera. ${ }^{57}$

En su último libro, La farsa del peronismo, el sindicalista del gremio de la carne radicalizó su crítica, sostuvo que el peronismo le había robado el sentido del 17 de octubre y denunció cómo había sido injustamente acusado y, bajo tortura, obligado a confesar un crimen que no cometió (organizar un complot para derrocar a Perón). En ese libro, Reyes formula (aunque en con otro referente) la misma pregunta que Osorio Lizarazo le trasmitió a Gaitán antes de su muerte: “¿Cómo pudo llegar el coronel Perón a producir este milagro de síntesis ideológica cuando sus partidarios provenían de rincones tan heterogéneos y opuestos dentro del espectro político, tales como la extrema derecha, el socialismo y el radicalismo?". ${ }^{58}$ En su respuesta, el líder sindical imbrica dos asuntos especialmente críticos: la disolución del laborismo como sinónimo del desvío ideológico del peronismo, elemento que habría permitido la conversión de un partido de masas obreras en un movimiento en el que confluían ideologías al extremo opuestas. Y, que dicho eclecticismo, había sido posible gracias al violento desplazamiento de quienes, como él, no habían aceptado las directrices de Perón.

Con un argumento análogo, en 1948 Osorio Lizarazo le escribió una carta a Gaitán en la que sostuvo un argumento similar: “[n]o hay en nación alguna un grupo más heterogéneo que el partido liberal de Colombia, en cuyo seno quieren [...] cohabitar y promiscuar las tendencias más opuestas e irreconciliables: el socialismo de estado con la doctrina de laissez-faire; el materialismo histórico con la creencia providencial de la historia [...] el trumanismo de Germán Arciniegas con el stalinismo de Eduardo Zalamea. ¿Cómo es posible que pueda haber unidad de criterio, de acción y de método entre gente tan dispersa

movimiento colectivo, dándoles así el impulso para pasar a la acción”. Juan Carlos Torre. La vieja guardia sindical y Perón... op. cit., 136.

${ }^{56} \mathrm{~A}$ un año del 17 de octubre se desarrollaron dos conmemoraciones paralelas, la organizada por la CGT y la de los laboristas, liderada por Reyes bajo el lema, "el día del pueblo". Esta fue la única vez que se desarrollaron festejos paralelos, en adelante la mirada de los laboristas sería desplazada por la oficial. Mariano Plotkin, El día que se inventó el peronismo. La construcción del 17 de Octubre. (Buenos Aires: Sudamericana, 2007), 169.

${ }^{57}$ Para Reyes, quienes realmente hicieron el 17 de octubre fueron hombres y mujeres trabajadores de los gremios autónomos entre quienes claramente se encuentran Luis Gay y María Roldán, aquellos nucleados en la CGT que desobedecieron las órdenes de la central, "estudiantes, profesionales, intelectuales, comerciantes, y distintos sectores de la pequeña industria nacional, delegaciones de los trabajadores de la carne de Uruguay, Brasil, de la FOTIA, de Tucumán, Rosario y Mendoza; grupos de los distintos partidos políticos tradicionales y gente independiente" que engrosaron las filas de los trabajadores. Cipriano Reyes. Yo hice el 17 de octubre... op. cit., 11.

${ }^{58}$ Cipriano Reyes. La farsa del peronismo... op. cit., 7. 
y tan distanciada moral, económica e ideológicamente?". 59 Pero si para el escritor colombiano su interrogante no tendría resolución en Gaitán ni el Partido Liberal, sí la tendría llamativamente en Perón y el peronismo.

\section{J. A. Osorio Lizarazo, "la aventura de un gaitanista-peronista" y la invención de la permanente presencia de Gaitán}

José Antonio Osorio Lizarazo (1900-1964) fue periodista, novelista, ensayista y gaitanista de primera hora. Sus ficciones son consideradas exponentes de la novela urbana y de la crónica popular colombiana de mediados de los años cuarenta. Fue director del periódico gaitanista Jornada durante su primera época (1944-1946). Se unió al gaitanismo con motivo de la campaña presidencial que Jorge Eliécer Gaitán inició en 1944 para competir en las elecciones de 1946. Su papel fue fundamental en la creación y dirección del periódico, pero el estrecho vínculo político y de amistad personal con Gaitán comenzó a diluirse cuando el líder lo apartó del vocero gaitanista en 1945. A partir de entonces y hasta 1947, sus críticas y cuestionamientos asumieron un carácter escabroso. Ese año $-\mathrm{y}$ luego de haber atravesado una serie de avatares políticos, como la fugaz experiencia de la Unión Nacional Izquierdista Revolucionaria (UNIR) ${ }^{60}$ y el regreso de Gaitán al Partido Liberal— el líder finalmente se convirtió en Jefe Único del partido y emprendió un proceso de liberalización del gaitanismo.

El retorno de Gaitán a las filas liberales no se produjo sin tensiones. En efecto, en las elecciones de 1946 se presentaron dos candidaturas bajo el arco del liberalismo, la de Gabriel Turbay, candidato oficial del partido y la de Jorge Eliécer Gaitán. Desde la mirada de los liberales, Gaitán era un disidente y su desobediencia era la responsable de que Mariano Ospina Pérez haya puesto fin a la República Liberal. ${ }^{61}$ Pero si Gaitán tenía que negociar con los jefes tradicionales en el seno de un partido que no le perdonaba sus intentos por desarticular la vieja política bipartidista, el tribuno popular (como le decían sus militantes) debía enfrentar también las duras acusaciones de gaitanistas de primera hora, que veían cómo el movimiento se transformaba a medida que se "liberalizaba" y se extendía a lo largo del territorio nacional.

La imagen que sintetizó la nacionalización del movimiento y su auto-reconocimiento como un movimiento nacional, fue la denominada "Marcha de las Antorchas" del 18 de julio

\footnotetext{
59 “Carta de J. A. Osorio Lizarazo dirigida a Jorge Eliécer Gaitán”, (Buenos Aires, marzo 11 de 1948), Archivo General de la Nación, Colombia, Fondo Jorge Eliécer Gaitán, p.4, Folio 0119.

${ }^{60}$ La UNIR (1933-1935) fue una experiencia fugaz pero quedó clavada en la memoria de los primeros gaitanistas. Allí Gaitán había intentado llevar a la práctica su versión del liberalismo, de corte social, nacionalista, popular y revolucionario. Para ello tuvo que diferenciar su proyecto tanto del Partido Liberal, fuerza de la que provenía y a la que pronto debió retornar, y del Partido Conservador. El discurso unirista se construyó desde una doble frontera política (liberal - conservadora), una multiplicidad de enemigos y escasas articulaciones políticas. Sin embargo, si el unirismo no fue una experiencia política duradera, constituyó un válido ensayo de organización y de identificación política.

${ }^{61}$ Pues sumados los votos obtenidos por los dos candidatos liberales el Partido Liberal resultaba mayoritario respecto de los votos de los conservadores.
} 
de 1947. La manifestación, concebida bajo la metáfora del río de candela, fue un verdadero exponente de la exhaustiva organización gaitanista, la cual contaba con capitanes por cuadras en los barrios populares. ${ }^{62}$

"Aquí se supo que el movimiento era nacional. Recuerdo [...] unos indios, que al llegar cansados a la Manifestación le dijeron [a Gaitán]: 'Doctor, echando remo por toda la selva llegamos aqui'. El Doctor hizo alusión a esto en su discurso". 63

Las movilizaciones cumplían un doble papel, en términos de sus contenidos denunciaban la violencia contra gaitanistas y liberales, constituían básicamente una demanda de paz, pero en sus repertorios y modalidades también eran mensajes dirigidos directamente a la clase política, en los que el gaitanismo visibilizaba la organización interna del movimiento, el control que Gaitán tenía sobre las multitudes y la respuesta efectiva de las mayorías a las directrices del líder.

A pesar de la positiva respuesta de la militancia a las directrices de Gaitán y no sólo de ella, vale decirlo, ${ }^{64}$ entre 1946 y 1947, la vieja guardia gaitanista no dejaría de reclamar los repentinos cambios en la organización interna del movimiento y en la coordinación de las manifestaciones. Los antiguos comités gaitanistas dejaron de funcionar y el gaitanismo, que había pasado por la experiencia desafortunada del unirismo, debía constituirse como representación oficial del liberalismo.

Osorio Lizarazo hacía parte de esa tradición identificada con un gaitanismo revolucionario e intransigente, que se opuso a la inclusión en su propio seno de quienes, para él, profesaban un liberalismo de tinte oligárquico. Hacia 1946 los cuestionamientos de Osorio a Gaitán se hicieron evidentes cuando el periódico liberal El Tiempo, publicó un artículo titulado La aventura de un gaitanista. Allí Osorio calificaba a Gaitán como "agitador, demagogo e incapaz”, capitán de manzanillos, estirpe política que labora en su propio beneficio. ${ }^{65}$

"El doctor Gaitán, que como agitador y como demagogo no tiene par en muchos de nuestros países, como jefe y como hombre de acción es inepto e incapaz [...]. Personalmente, yo tengo, a mi pesar, un temperamento revolucionario. No soy, ni he sido, ni seré nunca, un político [...] Por sobre

\footnotetext{
${ }^{62}$ Pedro Garzón, quien luego se retiraría del gaitanismo para formar parte del PC colombiano, fue una figura clave en la coordinación de las multitudinarias manifestaciones gaitanistas.

${ }^{63}$ José García, presidente del comité gaitanista del barrio La Perseverancia, uno de los sectores más combativos del movimiento. En: Arturo Alape. El Bogotazo: memorias del olvido. (Bogotá: Editorial Planeta, 1985), 66.

${ }^{64}$ De hecho, a través de la oposición pueblo - oligarquía, el gaitanismo intentaba incluir en su propio campo identitario a militantes conservadores, claro está no se trataba de dirigentes. Los militantes gaitanistas señalaban la presencia en las manifestaciones de bases populares provenientes del conservatismo. De acuerdo con Julio Ortiz Márquez, político liberal y amigo de Gaitán, "había muchos conservadores gaitanistas, que simpatizaba con Gaitán. Porque Gaitán decía que el hambre no era liberal ni conservadora y que la corrupción no era tampoco ni conservadora ni liberal, sino clasista". Julio Ortiz Márquez, En: Arturo Alape, op. cit., 33.

${ }^{65}$ José Antonio, Osorio Lizarazo, El Tiempo, 31 dic. 1946. En: J. A. Osorio Lizarazo, La aventura de un gaitanista. Novelas y crónicas. (Bogotá: Instituto Colombiano de Cultura, 1978 [1946]), 559-560.
} 
todas las cosas, amo la sinceridad y la eficacia [...] Por la misma causa me puse al servicio del movimiento gaitanista y le dediqué mis modestas energías, mi experiencia de escritor, mi fe de revolucionario, impulsado por un ideal que encarnaba en el gran tribuno y que no se reducía ni a empleo ni a curul. Yo sigo siendo invulnerable en mis puntos de vista; pero mi ilustre jefe es ahora un modesto capitán de manzanillos". ${ }^{66}$

Casi como lo dijo Cipriano Reyes al referirse a los radicales renovadores, que una vez lograda la "decretada" unidad "estarían contentos junto al nuevo 'jefe indiscutido', dispuestos a prestarle todas las 'asesorías necesarias' para que en adelante todo se hiciera como Perón deseaba!", ${ }^{67}$ Osorio Lizarazo no podía olvidar que quienes acompañaban a Gaitán en la coyuntura del 46 eran sus antiguos enemigos, calificados por el propio Osorio como mercenarios de ideologías que no dudarían en desbandarse cuando la fortuna dejara de acompañar al jefe. ${ }^{68}$

La cuestión que terminó de decepcionar al ex director de Jornada fue que Darío Samper, quien había dirigido el semanario liberal Batalla, órgano de apoyo y difusión a la candidatura de Gabriel Turbay, se había convertido repentinamente al gaitanismo y participaba de la dirección de Jornada. En 1947 Samper ya era el único director del periódico gaitanista.

“[...] el doctor Darío Samper dirigía un semanario, Batalla, cuyo objetivo primordial era acusar al doctor Gaitán de haber estafado a las masas, enrostrarle su aventura de la Unir, enumerarle sus errores y sus debilidades, decorándolos con negros colores para hacerlos aparecer delictuosos; y hoy el doctor Darío Samper es uno de los voceros principales del gaitanismo, es el inspirador de Jornada y va a ser su director efectivo para ganarse su reelección". ${ }^{69}$

La disputa entre Osorio Lizarazo y Gaitán no daba para más. En 1947 el escritor emprendió un largo viaje por América Latina que él mismo denominó un exilio voluntario. En aquel periplo, que se prolongaría casi hasta su muerte, Argentina no fue la excepción. ${ }^{70}$

\footnotetext{
${ }^{66}$ Ibíd., 559-560.

${ }^{67}$ Cipriano Reyes. La farsa del peronismo... op. cit., 92.

${ }^{68}$ Así lo expresó en la carta dirigida a Gaitán: lo "que suele dar apariencia de unidad [al partido liberal es] la cooperación de la trashumancia política [...], esos trashumantes están en donde sea menester para recaudar provecho. [...]. Son los primeros que se desbandan, son los que buscan arrimo y amparo junto al jefe de turno para subsistir sin trabajar. Hoy están contigo. Ayer estuvieron contra ti con la máxima violencia. Mañana estarán otra vez rasgándose las vestiduras por la pesadumbre de haber sido tus amigos". Carta de Osorio Lizarazo a Jorge Eliécer Gaitán, marzo 11 de 1948, Buenos Aires. AGN, Colombia, p. 1 y 2, Folios 0116 y 0117.

${ }^{69}$ José Antonio, Osorio Lizarazo, El Tiempo, 31 dic. 1946. En: J. A. Osorio Lizarazo, La aventura de un gaitanista. Novelas y crónicas. (Bogotá: Instituto Colombiano de Cultura, 1978 [1946]), 556-564.

${ }^{70}$ Entre 1947 y 1960 Osorio Lizarazo emprendió un extenso viaje que incluyó estancias en Venezuela, primero, Argentina y Chile, después, y finalizó en República Dominicana. El escritor renunció a su último cargo público en Buenos Aires un año antes de la caída del peronismo y se dirigió a Chile. Luego no se dedicaría más a escribir sobre el gobierno argentino. Casi hacia el final de su vida, con varias dolencias en su cuerpo, entre ellas una sífilis contraída hace años, regresó a su tierra natal; pero las condiciones en las que volvió no fueron amigables,
} 
Trabajó allí como corresponsal para la prensa colombiana y luego de varios intentos (sin éxito) por obtener un puesto como diplomático en la Embajada de Colombia en Buenos Aires encontró el cobijo del gobierno peronista. ${ }^{71}$ Entre 1948 y 1954, los años porteños de Osorio Lizarazo, el autor se convirtió en una suerte de peronista-gaitanista y escribió en una clara defensa del gobierno argentino. La publicación de artículos periodísticos, la escritura de ensayos sobre la política social y económica del peronismo y su desempeño al servicio de la propaganda pública, hicieron de él una suerte de traductor del peronismo en Colombia y del gaitanismo en Argentina.

Un mes antes del asesinato de Gaitán, desde el barrio porteño de Villa Crespo, Osorio Lizarazo le escribió una carta a su jefe en la que le informaba la coincidencia entre el pensamiento y el programa de Gaitán con la política llevada a cabo por el gobierno peronista. A través de la figura de Perón, Osorio intentaba persuadir al líder colombiano de encauzar un verdadero proyecto revolucionario en Colombia, uno puramente popular y sin vacilaciones legales:

"[...] es indispensable también, mi querido Jorge, que nuestra generación se dé cuenta de que este no es el mundo de Santander [...]. Nuevos problemas han surgido. [...] Otros conceptos han aparecido, de justicia, de posición del Estado ante el pueblo, de sentido vital de ese mismo pueblo. [...] Todo eso es indispensable, pero no se realizará [...] porque refugiamos en la teoría de los métodos legales, la gran cobardía [...]. Yo estoy contemplando aquí en la Argentina la revolución que nosotros no podremos hacer, porque de no haberla embarcado tú, no hay otro caudillo ni otro jefe posible en el presente ni en el inmediato porvenir [...].

[En Argentina] [...] la propiedad nacional [...] fue reivindicada en su totalidad por el Estado. La política social ha seguido un proceso acelerado de justicia, por medio de nuevas prestaciones, [...] de la retribución equitativa para el esfuerzo personal, del derecho a vivir que tiene todo hombre sobre la tierra [...].

Toda esta obra, múltiple y diáfana, coincide con tu pensamiento y con tu programa de los grandes días de la lucha presidencial, en que tú hubieras podido encabezar una revolución auténtica y definitiva. Tú y nadie más. [...]. Perón ha ascendido a la categoría casi mítica de la devoción popular. Yo no lo digo: te lo informo objetivamente. Por qué? Porque no procedió con engaños, ni se abatió con las derrotas, ni se doblegó ante el desafío de las oligarquías, ni se detuvo en el camino, ni compensó el asesinato de su pueblo con silenciosos e inofensivos desfiles" ${ }^{72}$

\footnotetext{
ya derrocado Rojas Pinilla, fue criticado y señalado como propagandista de Rojas y "autor por encargo" de Perón y de Trujillo. Véase: Oscar Calvo Isaza "Biografía de nadie..." op. cit.

${ }^{71}$ Osorio Lizarazo logró ser contratado en la oficina de información de la Casa Rosada durante el primer gobierno peronista y, durante el segundo gobierno de Perón, en el Instituto de las Ciencias del Hombre dependiente del Ministerio de Salud. Oscar Calvo Isaza "Biografía de nadie..." op. cit. Sus labores en Argentina están documentadas en el Fondo José Antonio Osorio Lizarazo (JOAL), Biblioteca Nacional, Colombia.

72 "Carta de J. A. Osorio Lizarazo dirigida a Jorge Eliécer Gaitán", (Buenos Aires, marzo 11 de 1948), AGN, Colombia, Fondo Jorge Eliécer Gaitán, p.3 y 4, Folios 0118 y 0119.
} 
En el cruce con la experiencia argentina, Osorio cuestionaba a las vacilaciones revolucionarias de Gaitán. Vacilaciones que, para él, creaban una brecha insalvable entre un Gaitán agitador que deseaba hacer de Colombia una nación más justa y sus seguidores más leales, revolucionarios y combativos, formados en los años uniristas y en la campaña del 44. De hecho, en la biografía que el cronista de la miseria urbana escribió sobre el líder, confesó haberle propuesto un plan a Gaitán para realizar un golpe de Estado, pero las normas constitucionales serías siempre un límite insoslayable que el líder no estaría dispuesto a transgredir.

"El viejo y cordial amigo de Gaitán [en alusión a J.A. Osorio Lizarazo] [...] concibió un plan para imponer la voluntad del pueblo y aprovechar el ambiente agitado y de sedición que había creado la oratoria de Gaitán. Pero el jefe se echó a reír, rechazó la propuesta y anunció que jamás intentaría una revolución de esa naturaleza". ${ }^{73}$

Para Osorio, Gaitán no era Perón, la contradicción fundamental del colombiano era la de ser un revolucionario y un abogado al mismo tiempo. Su posición "encallaba en el absurdo" pues "todo el cuerpo constitucional y legislativo se había estructurado para la defensa del privilegio, para dar jurisprudencia a la injusticia, para aplastar al trabajador". Ninguna revolución podía llevarse a cabo "dentro de la ley", porque precisamente una revolución consistía "en romper la columna vertebral de la ley". ${ }^{74} \mathrm{El}$ costo de la indeclinable defensa de la norma por parte de Gaitán sería el carácter imposible de una verdadera revolución popular en Colombia. En primer lugar, porque para el escritor sólo Gaitán podía emprender una revolución popular, por lo que su negativa volvía a al proyecto revolucionario un horizonte imposible. Y, en segunda instancia, porque a la oligarquía colombiana (liberal-conservadora) no se la podía combatir con sus propias reglas electorales. A la violencia perpetrada contra el pueblo gaitanista en las veredas y campos de Colombia no se la podía liquidar con "silenciosos e inofensivos desfiles", en una clara alusión a la Manifestación del Silencio. ${ }^{75}$ El repertorio del silencio constituía una manera de visibilizar el carácter casi funeral de la situación de violencia sufrida por liberales y gaitanistas. Pero un mes antes del magnicidio, para quien seguía el rastro del líder colombiano proyectando sobre Perón todo aquello que Gaitán nunca podría ser, orar por la paz en medio de las masacres era sinónimos de una huida. $^{76}$

${ }^{73}$ J. A. Osorio Lizarazo, Gaitán, vida muerte y permanente presencia. (Bogotá: El Áncora Editores, 1998 [1952]), 275-276.

${ }^{74}$ Ibid., 276.

${ }^{75}$ El 7 de febrero de 1948 se llevó a cabo una de las más grandes movilizaciones gaitanistas, la Manifestación del Silencio, en la que el líder denunció en su famoso discurso, la Oración por la paz, el exterminio de las mayorías liberales en manos del régimen conservador.

${ }^{76}$ Algo similar señaló Luis Eduardo Ricaurte, lugarteniente de Gaitán, activista en los barrios: "[en la Marcha del Silencio] no hubo un solo grito. Pero fue el acto de cobardía de Gaitán, un acto de rendición, porque ya la violencia hacía estragos en los campos de Colombia". Luis Eduardo Ricaurte. En: Arturo Alape, op. cit. 102. 
Lo interesante de las críticas de Osorio Lizarazo, es que se fundamentaban en los conceptos elaborados por el propio Gaitán y en las metáforas utilizadas por él en sus discursos. Para Osorio había dos maneras de hacer política, la de los maquiavélicos traficantes del odio popular frente a quienes aman verdaderamente al pueblo y luchan por su bienestar y su dignidad. La primera versión, remite a la política tradicional de la oligarquía liberal y conservadora, los detractores del pueblo, mientras que la segunda es propia de la verdadera política, la revolucionaria, defensora de los intereses populares, la puramente gaitanista. Esta distinción no era más que una resignificación de la famosa metáfora de Gaitán sobre "el país político y el país nacional". A través de la lucha fundamental entre esos dos países que habitaban en Colombia, Gaitán había puesto en evidencia que la oligarquía vive y prospera tanto en el liberalismo como en el conservatismo, y que el pueblo también se compone por liberales y conservadores.

"En Colombia hay dos países: el país político que piensa en sus empleos, en su mecánica y en su poder, y el país nacional que piensa en su trabajo, en su salud, en su cultura, desatendidos por el país político. El país político tiene rutas distintas a las del país nacional ¡Tremendo drama en la historia de un pueblo!". ${ }^{77}$

Luego del 9 de abril la posición de Osorio Lizarazo sobre los desvíos de su líder tomó otro sentido. Poco menos de un mes transcurrió entre la escritura de aquella carta y el asesinato de Gaitán. El 9 de abril sorprendió a Osorio en Buenos Aires. Luego del trágico desenlace de los acontecimientos, el "destierro" y el distanciamiento con el gaitanismo adquirieron otro significado. Lejos de Colombia, muerto Gaitán y recluido el movimiento, la identificación positiva con el líder no sólo era posible sino necesaria. En Argentina, Osorio se dedicó a escribir sobre Gaitán, el gaitanismo y el 9 de abril. En 1952 publicó, bajo el sello editorial López Negri, El día del odio, la trágica novela que relata el 9 de abril y recrea las penurias y la miseria del pueblo colombiano durante los años cuarenta; ${ }^{78}$ y la primera biografía sobre Gaitán, Gaitán. Vida, muerte y permanente presencia ${ }^{79}$ En ella Osorio Lizarazo perdona pero no olvida. Perdona al hombre que fue Gaitán y no desaprovecha las letras para precisar quiénes fueron sus amigos más leales frente a los oportunistas que, como Darío Samper, no habían perdido ocasión para adherir a todos los jefes de turno.

Al igual que la autobiografía de Cipriano Reyes, la biografía de Osorio Lizarazo relata un hecho trágico desde una trama romántica. Aunque claramente si Reyes se coloca a sí mismo como héroe no reconocido (él es todo lo que Perón no), Osorio Lizarazo ubica a Gaitán como

\footnotetext{
${ }^{77}$ Discurso de Jorge Eliécer Gaitán "El país político y el país nacional” pronunciado en 1945. En: Jorge, M. Eastman, (Comp.) Jorge Eliécer Gaitán. Obras selectas. (Bogotá: Cámara de Representantes, 1979$), 162$.

${ }^{78}$ J. A. Osorio Lizarazo, El día del odio. (Buenos Aires: Ediciones López Negri, 1952).

${ }^{79}$ Hasta 1978 fue la principal fuente en los estudios sobre la vida de Gaitán. Ese año apareció la primera biografía escrita por un narrador no-testigo y no-colombiano: Richard Sharpless. Gaitán of Colombia: a political biography. (Pittsburgh: University of Pittsburgh Press, 1978).
} 
una promesa de plenitud revolucionaria que, a pesar de su radical ausencia, permanece presente. La clave interpretativa se encuentra al final del relato, pues el cierre organiza, retrospectivamente, su sentido. Gaitán ya no necesita corporizarse en un hombre-líder para permanecer en la vida política de Colombia porque, a pesar de la naturaleza monstruosa de su asesinato, el carácter inconcluso de su revolución se convierte en un mandato de búsqueda de justicia que permanecerá vivo en los corazones del pueblo. Este es, para Osorio, el principal legado del gaitanismo, una identidad política ya no partidaria y, precisamente por ello, un arma mucho más eficaz: la eterna presencia de lo que Gaitán pudo haber sido para el pueblo colombiano.

\section{A modo de cierre: contrapuntos entre actos identificarios, singulares pero significativos}

Lejos de posicionarlos como auténticos fundadores, detractores o como enemigos internos del peronismo y del gaitanismo, a lo largo de este artículo analizamos sucesivos actos identificatorios de Cipriano Reyes y de Osorio Lizarazo como un proceso. Bajo este prisma, la identidad política de ambos no se constituyó "de una vez y para siempre", ni fue inmune al devenir histórico de sus propias vidas, la de los movimientos políticos y la de los líderes. Ciertamente, la trayectoria de los líderes abrió y cerró posibilidades identificatorias. En el caso de Osorio, la muerte (y el tipo de muerte) de Gaitán lo convirtieron en su biógrafo amigo. El escritor construyó una representación de sí mismo como un verdadero gaitanista, en ocasiones más gaitanista que el propio Gaitán. Para ello apeló al pensamiento y los conceptos construidos por el líder y se los devolvió críticamente para cuestionar decisiones políticas claves adoptadas por él (como su negativa a realizar un golpe de Estado, la integración de liberales y antiguos enemigos en el seno del movimiento, y el sentido que el horizonte revolucionario debía tener). En el caso de Reyes, la presencia de un líder derrocado y exiliado, pero que siguió interviniendo en la realidad política del país hasta su muerte (en 1974), lo acercaron a un proceso de identificación que tozudamente no renunció a las durísimas críticas ni a la defensa indeclinable de los primeros sentidos producidos durante la emergencia del peronismo (justicia social, la consecución de una vida mejor, la dignidad humana del pueblo trabajador, entre otros), cuestiones que hicieron de él un biógrafo de sí mismo.

Aunque singulares los actos identificatorios de Reyes y de Osorio Lizarazo comparten algunas características significativas para la comprensión de los populismos y las identidades políticas. Los cuestionamientos de ambos a la heterogeneidad de los movimientos, las resistencias y oposiciones a la inclusión de miembros no "plenamente laboristas" ni "puramente gaitanistas", nos permiten alertar cómo estas tensiones y conflictos internos han servido para nombrar algunas características propias de los populismos, las cuales lejos de representar "lo otro de la democracia" ponen nombre a las dificultades y desafíos que impone esa lógica política. Para expresarlo en palabras de los autores referenciados al comienzo del 
artículo, las intolerancias y resistencias de Cipriano Reyes y de Osorio Lizarazo al tipo heterogeneidad interna que comenzaron a asumir los movimientos, ponen de manifiesto que las figuras aquí analizadas aspiraban a construir comunidades políticas sin contaminaciones. A su manera, estos actores pretendieron hacer de los movimientos espacios identiarios homogéneos, con procesamientos de las alteridades mucho más parecidos a las identidades populares totales que aquellas con pretensión hegemónica.

En las trayectorias y los procesos identificatorios de ambos actores persiste una tensión entre los llamados a la construcción de una unidad política por parte de los líderes y las tensiones internas que esa unidad produce, pues esta no se sustenta en un principio identitario de homogeneidad subyacente sino que, por el contrario, supone la constante negociación de la propia identidad con los adversarios y con nuevos sectores integrados a los movimientos. Aquí hemos enfatizado cómo esas tensiones y heterogeneidades suponen férreos enfrentamientos con actores fundacionales de los movimientos. Reyes y Osorio Lizarazo, no cedieron a las nuevas prácticas y dinámicas que imprimieron los "recién llegados", no aceptaron formar parte del campo opositor $\mathrm{y}$, en circunstancias concretas, tampoco se sintieron miembros plenos de la nueva comunidad política. Quizás, es en este nivel de heterogeneidad (interna al propio campo identitario) que la lógica binaria amigo-enemigo se vuelve analíticamente improductiva.

Finalmente, creemos que al focalizar en las trayectorias individuales y de figuras mediadoras, nuestro trabajo abre también la discusión a la posibilidad de pensar procesos identitarios en pequeñas escalas, es decir a niveles micro sociales y de hacerlo de manera no divorciada de lo colectivo. O dicho de otro modo, los sucesivos actos identificatorios de figuras, actores y sujetos en el plano individual permiten pensar de otro modo los procesos populistas "más generales". Identificarse (o no) como peronista y como gaitanista requiere entonces de un análisis procesual, o del conjunto de actos identificatorios que, como vimos, pueden o no guardar coherencia a lo largo del tiempo.

Consideramos que a través de estos rastros identitarios, singulares pero significativos, debería quedar claro que el peronismo y el gaitanismo no se reducen a aquello que el propio Perón o que el propio Gaitán definieron sobre sí mismos, sobre sus proyectos políticos o los movimientos políticos que signaron. Fueron mucho más que eso, incluso aquello que no les gustó sobre sus miembros, militantes e intelectuales. Sentidos que sobrevivieron latentes a los avatares de los procesos políticos de ambos países. 


\section{Referencias bibliográficas}

\section{Fuentes primarias \\ Archivo}

Archivo General de la Nación (AGN), Bogotá-Colombia. Fondo Jorge Eliécer Gaitán. Osorio Lizarazo, J. A. “Carta dirigida a Jorge Eliécer Gaitán”, Buenos Aires, marzo 11 de 1948. Pág. 1-5, Folios 0116 a 0120.

\section{Publicaciones periódicas}

Redacción. "La olvidada historia de la mujer que lideró el 17 de octubre en Berisso". Pregoneros gráficos, periódico digital de los trabajadores gráficos. Sindicato de artes gráficas de Mendoza, 2018, Octubre, 18. [En línea] https://pregonesgraficos.com.ar/la-olvidadahistoria-la-mujer-lidero-17-octubre-berisso/ [consultado el 24/01/2018].

\section{Documentación primaria impresa}

Eastman, Jorge M. (Comp.) Jorge Eliécer Gaitán. Obras selectas. Tomo I y II. Bogotá: Cámara de Representantes, 1979.

Osorio Lizarazo, J. A. La cara de la miseria. Bogotá: Talleres de Ediciones Colombia, 1926.

Osorio Lizarazo, J. A. Gaitán, vida muerte y permanente presencia. Bogotá: El Áncora Editores, (1998 [1952]).

Osorio Lizarazo, J. A. El día del odio. Buenos Aires: Ediciones López Negri, 1952.

Osorio Lizarazo, J. A. La aventura de un gaitanista. Novelas y crónicas. Bogotá: Instituto Colombiano de Cultura, (1978 [1946]).

Reyes, Cipriano. ¿Qué es el laborismo? Buenos Aires: Ediciones R.A, 1946.

Reyes, Cipriano. Yo hice el 17 de octubre. Buenos Aires: Editorial G-S, 1973.

Reyes, Cipriano. La farsa del peronismo. Testimonio implacable del dirigente sindical del 17 de Octubre que muestra al desnudo al Justicialismo y a sus protagonistas. Buenos Aires: Sudamericana, 1987.

\section{Fuentes secundarias}

Aboy Carlés, Gerardo. "De lo popular a lo populista o el incierto devenir de la plebs". En Las brechas del pueblo. Reflexiones sobre identidades populares y populismo, editado por Aboy Carlés, G., et. al. Buenos Aires: UNGS-UNDAV Ediciones, 2013, 17-40.

Aboy Carlés, Gerardo. "El nuevo debate sobre el populismo y sus raíces en la transición democrática: el caso argentino". Revista Colombia Internacional. N. 82 (2014) pp. 35-44. [En línea], DOI: dx.doi.org/10.7440/colombiaint82.2014.02 [consultado el 30/03/2020].

Aboy Carlés, Gerardo. "Populismo, regeneracionismo y democracia". POSTData, vol. 15, No1, (2010). pp. 11-30. [En línea] http://www.revistapostdata.com.ar/2012/01/populismo-regeneracionismoy-democracia-gerardo-aboy-carles/ [consultado el 30/03/2020].

Acha, Omar y Quiroga, Nicolás. El hecho maldito. Conversaciones para otra historia del peronismo. Buenos Aires: Prohistoria, 2012.

Arciniegas, Germán. Entre la libertad y el miedo. Buenos Aires: Editorial Sudamericana, 1956 [1951]. Alape, Arturo. El Bogotazo: memorias del olvido. Bogotá: Editorial Planeta, 1985. 
Altamirano, Carlos. Para un programa de historia intelectual y otros ensayos. Buenos Aires: Siglo XXI, 2005.

Amadeo, Mario. Ayer, hoy y mañana. Buenos Aires: Ediciones Gure, 1956.

Braun, Herbert. Mataron a Gaitán. Vida pública y violencia urbana en Colombia. Bogotá: Editorial Aguilar, 2008 [1985].

Martín-Barbero, Jesús. De los medios a las mediaciones. Comunicación, cultura y hegemonía. Bogotá: Convenio Andrés Bello, 2003.

Martín-Barbero, Jesús. Comunicación masiva, discurso y poder. Quito: Editorial Época, 1978.

Barros, Sebastián. "Polarización y pluralismo en la teoría de la hegemonía de Ernesto Laclau". Latinoamérica. Revista de Estudios Latinoamericanos. Nro 67/2. Octubre (2018). pp. 15-38. [En línea], DOI: http://dx.doi.org/10.22201/cialc.24486914e.2018.67.57079. [consultado el 30/03/2020].

Barros, Sebastián. "Despejando la espesura. La distinción entre identificaciones populares y articulaciones políticas populistas". En: Las brechas del pueblo. Reflexiones sobre identidades populares y populismo, editado por Aboy Carlés, G., et. al. Buenos Aires: UNGS-UNDAV Ediciones, 2013, 41-64.

Barros, Sebastián. "Momentums, demos y baremos. Lo popular en los análisis del populismo Latinoamericano". POSTData, vol. 19, núm. 2, octubre, (2014), pp. 315-344. [En línea], http://www.revistapostdata.com.ar/2014/11/momentums-demos-y-baremos-lo-popular-en-losanalisis-del-populismo-latinoamericano-sebastian-barros/[consultado el 30/03/2020].

Barros, Sebastián. "Terminando con la normalidad comunitaria. Heterogeneidad y especificidad populista". Studia Politicae, N ${ }^{o}$ 20, Otoño, (2010). pp. 121-132. [En línea], https://dialnet.unirioja.es/servlet/articulo?codigo=3980169[consultado el 30/03/2020].

Calvo Isaza, Oscar. "Biografía de nadie: José Antonio Osorio Lizarazo (1900-1964)". Tesis de Maestría, Escuela Nacional de Antropología e Historia. Ciudad de México, 2005.

Casullo, María Esperanza. ¿Por qué funciona el populismo?. Buenos Aires: Siglo XXI, 2019.

Del Campo, Hugo. Sindicalismo y peronismo. Los comienzos de un vínculo perdurable. Buenos Aires: Siglo XXI, 2005 [1983].

Germani, Gino. Política y sociedad en una época de transición. De la sociedad tradicional a la sociedad de masas. Buenos Aires: Paidós, 1962.

Halperín Donghi, Tulio. "Del fascismo al peronismo", en Argentina en el callejón. Buenos Aires: Ariel, 1994 [1956].

James, Daniel. Doña María: historia de vida, memoria e identidad política. Buenos Aires: Manantial, 2004.

Laclau, Ernesto. La razón populista. Buenos Aires: Fondo de Cultura Económica, 2005.

Magrini, Ana Lucía. Los nombres de lo indecible: populismo y Violencia(s) como objetos en disputa. Un estudio comparado del peronismo en Argentina y el gaitanismo en Colombia. Buenos Aires: Prometeo, 2018.

Magrini, Ana Lucía. "Apuntes metódicos para una historia y política como significación”. En Métodos: aproximaciones a un campo problemático. Farrán, Roque, et. al. Buenos Aires: Prometeo, 2018, 253-286.

Magrini, Ana Lucía y Quiroga, María Virginia. "Comunicación y política en el cruce de las perspectivas de Jesús Martín-Barbero y de Ernesto Laclau”. Studia Politicae, No 41, otoño (2017). pp. 89- 
104. [En línea], https://dialnet.unirioja.es/servlet/articulo?codigo=6197257[consultado el 30/03/2020].

Nállim, Jorge. Las raíces del antiperonismo. Orígenes históricos e ideológicos. Buenos Aires: Capital Intelectual, 2014.

Neiburg, Federico. Los intelectuales y la invención del peronismo. Buenos Aires: Alianza Editorial, 1998.

Palacios, Marco. El populismo en Colombia. Bogotá-Medellín: Editorial Siuasinza.- Ediciones Tigra de Papel, 1971.

Perelman, Ángel. Cómo hicimos el 17 de octubre. Coyoacán. Buenos Aires, 1961.

Plotkin, Mariano. El día que se inventó el peronismo. La construcción del 17 de Octubre. Buenos Aires: Sudamericana, 2007.

Torre, Juan Carlos y Pastoriza, Elisa "La democratización del bienestar", en Nueva Historia Argentina. Torre J. C. (Dir.), Tomo VIII. Buenos Aires: Sudamericana, 2002, p. 257-313.

Torre, Juan Carlos. La vieja guardia sindical y Perón. Sobre los orígenes del peronismo. Buenos Aires: Editorial Sudamericana - Instituto Torcuato Di Tella, 1990.

Torre, Juan Carlos. "Interpretando (una vez más) los orígenes del peronismo”, en Mackinnon, María Moira y Petrone, Mario Alberto (Comp.) Populismo y neopopulismo en América Latina. El problema de la Cenicienta. Buenos Aires: EUDEBA, 1999 [1989], 173-196.

Raanan Rein. "Repensando el populismo en América Latina: el caso argentino", en Carreras Doallo, Ximena y Mateo, Graciela (Comp.) Entre viejos y nuevos populismos. Editorial CICCUS, 2019, 93-112. Ebook. Disponible en: https://ciccus.org.ar/libro/entre-viejos-y-nuevos-populismos/

Sharpless, Richard. Gaitán of Colombia: a political biography. Pittsburgh: University of Pittsburgh Press, 1978.

Zuleta Pardo, Mónica. La voluntad de verdad de Colombia: una genealogía de las ciencias sociales profesionales. Bogotá: Universidad Central, 2011. 